\title{
Apnoea after THAM Administration in the Newborn
}

\author{
N. R. C. ROBERTON* $\uparrow$ \\ From the Neonatal Research Unit, Institute of Child Health, Hammersmith Hospital, London
}

\begin{abstract}
Roberton, N. R. C. (1970). Archives of Disease in Childhood, 45, 206. Apnoea after THAM administration in the newborn. The use of THAM in the treatment of neonatal acidaemia is surveyed over a 3-year period. Of 100 babies to whom the drug was given while they were breathing spontaneously, $17 \%$ had respiratory depression during, or within two minutes of injection. If only potentially viable babies are considered, the incidence of respiratory depression increases to $20 \%$ and the incidence in babies with respiratory distress is $17 \%$. No single group of babies was particularly susceptible to this action of THAM, except those who had had a previous spontaneous apnoeic attack. No babies became apnoeic after the injection of sodium bicarbonate. It appears that in the 'good prognosis' group according to the hyperoxia test those babies who require correction of their $p \mathrm{H}$ have a higher death rate than those who do not. There was no statistically significant increase in the death rate of babies who deteriorated after THAM, but several of these babies only survived after treatment with artificial ventilation. There was an increased incidence of intraventricular haemorrhage in those babies who received $7 \%$ THAM rather than $3.6 \%$ THAM, but this may be due to other factors in their illness.
\end{abstract}

The respiratory distress syndrome (RDS) in the newborn baby is characterized by the clinical triad of tachypnoea, expiratory grunting, and inspiratory retraction (Rudolph and Smith, 1960). Such babies have a combined respiratory and metabolic acidosis (Oppé, Priestley, and Redstone, 1965), and their routine care now includes correction of the $\mathrm{pH}$ with either sodium bicarbonate or tris (hydroxymethyl) aminomethane (THAM, trometamol) (Troelstra et al., 1964; Gupta, Dahlenburg, and Davis, 1967; Usher, 1963; Hutchison et al., 1964). In the presence of pulmonary disease THAM has a theoretical superiority over sodium bicarbonate, which requires an open system to be an effective buffer. THAM reacts directly with dissolved $\mathrm{CO}_{2}$ in the plasma forming a cation (excreted in the urine), and liberates one bicarbonate ion in the process without adding sodium ions to the circulation (Fig.) (Nahas, 1963; Strauss, 1968).

During recent years it has been our policy on the

Received 4 August 1969.

^Percy J. Neate Research Fellow of the Clothworkers' Company. †Present address: Nuffield Institute of Medical Research, Oxford. neonatal unit at Hammersmith Hospital to correct acidaemia in babies with THAM, given as a single intravenous injection rather than by slow infusion, and to repeat the dose as required until the $p \mathrm{H}$ is corrected. We observed that some babies suffered respiratory depression or apnoea during the injection. For this reason, THAM was only administered when a member of the medical staff was present who was experienced in intubation and resuscitation of the premature newborn baby. We have now reviewed the notes of all babies who received THAM in 1965, 1966, 1967, looking for episodes of apnoea noted by either the medical or nursing staff after injection. For the purposes of this study, we defined respiratory depression as either frank apnoea, or a decrease in the amplitude $\sigma$ and frequency of respiration sufficient to cause $N$ cyanosis, occurring during the injection or within $N$ two minutes of the injection being completed. A smaller number of babies who received sodium bicarbonate during this period for treatment of $\stackrel{\bullet}{=}$ acidaemia were reviewed in the same way. We $\stackrel{\mathbb{N}}{\mathcal{N}}$ excluded from the analysis all babies who received either drug as part of the resuscitation procedure immediately after birth, when intermittent positive pressure respiration (IPPR) was also being applied. 


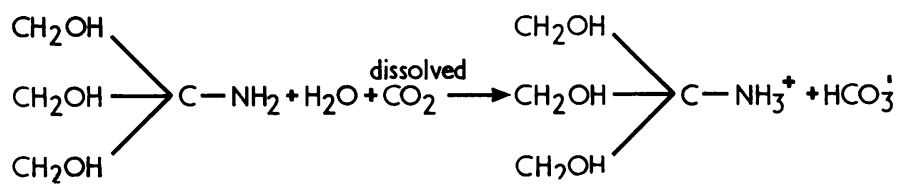

FIG.-Chemical reaction of dissolved $\mathrm{CO}_{2}$ with THAM.

\section{Methods}

The THAM was given as a solution of THAM hydrochloride in water with a $p \mathrm{H}$ of $8 \cdot 64$. $3 \cdot 6 \%$ THAM (0.3 molar-isotonic) or $7.0 \%$ THAM $(0.58$ molar-hypertonic) was used. The sodium bicarbonate was administered as an $8.4 \%$ solution which is hypertonic and contains $1 \mathrm{mEq} / \mathrm{ml}$. The solutions were injected into the umbilical venous catheter or occasionally into the umbilical arterial catheter, usually taking 2-3 minutes for a $10 \mathrm{ml}$. injection. Slower rates were sometimes used. In other respects the management of the respiratory illness in all babies was identical, sufficient oxygen being administered to keep the lower aortic $\mathrm{P}_{\mathrm{a}} \mathrm{O}_{2}$ values, as measured on blood drawn from an umbilical artery catheter, in the range $60-90 \mathrm{~mm}$. Hg (Roberton et al., 1968).

\section{Results}

One hundred babies were given THAM when breathing spontaneously, and 17 developed significant respiratory depression (Table I); 2 of the 17 had cardiac arrests. 35 survived the neonatal period: 4 who became apnoeic (including both babies who had cardiac arrests) and 31 who did not. If we exclude non-viable babies, i.e. all babies of less than $1000 \mathrm{~g}$. birthweight and less than 28 weeks' gestation, and babies with major congenital malformations such as meningomyelocele and Potter's syndrome, 74 babies (including all survivors) received THAM and 15 became apnoeic. 65 of these 74 babies fulfilled our criteria for RDS at 4 hours of age (Roberton et al., 1968; Reynolds, Roberton, and Wigglesworth, 1968) and 11 of them developed respiratory depression following THAM. 33 babies with RDS survived the neonatal period, 36 who tolerated THAM and 3 who did not. The diagnoses in the 9 babies who did not have RDS are shown in Table II.

In terms of doses of THAM administered, 218 injections to 100 babies were followed by 17 episodes of respiratory depression, and if only potentially viable babies are considered, 169 injections of THAM to 74 viable babies were followed by 15 episodes of respiratory depression; and 139 injections of THAM to 65 babies with RDS were followed by 11 episodes of respiratory depression.

The post-mortem findings in the 66 babies who died are shown in Table III. The major cause of death was hyaline membrane disease, but there was also a high incidence of intraventricular haemorrhage (IVH) which was present in $\mathbf{1 8}$ out of the 38 potentially viable babies upon whom we obtained a post-mortem examination.

During this three-year period, 32 potentially viable babies were given 44 doses of sodium bicarbonate while breathing spontaneously. 23 of these babies fulfilled the diagnostic criteria for $\mathrm{RDS}$, and they received 34 doses of sodium bicarbonate. There were no episodes of respiratory depression after the injection of sodium bicarbonate alone. 4 babies received an injection of sodium bicarbonate and THAM simultaneously, and one of these deteriorated afterwards. It is worth noting that 6 babies, who tolerated sodium bicarbonate when breathing spontaneously, had

TABLE I

Mortality Rate and Incidence of Apnoea in Babies who Received THAM

\begin{tabular}{|c|c|c|c|c|c|c|c|}
\hline & \multicolumn{3}{|c|}{ THAM Tolerated } & \multicolumn{3}{|c|}{$\begin{array}{l}\text { Respiratory Depression } \\
\text { After THAM }\end{array}$} & \multirow{2}{*}{ Total } \\
\hline & Alive* & Dead & Total & Alive & Dead & Total & \\
\hline $\begin{array}{l}\text { All babies } \\
\text { Excluding previable babies and babies with major } \\
\text { congenital malformations } \\
\text { Babies with respiratory distress syndrome }\end{array}$ & $\begin{array}{l}31 \\
31 \\
30\end{array}$ & $\begin{array}{l}52 \\
28 \\
24\end{array}$ & $\begin{array}{l}83 \\
59 \\
54\end{array}$ & $\begin{array}{l}4 \\
4 \\
3\end{array}$ & $\begin{array}{r}13 \\
11 \\
8\end{array}$ & $\begin{array}{l}17 \\
15 \\
11\end{array}$ & $\begin{array}{r}100 \\
74 \\
65\end{array}$ \\
\hline
\end{tabular}

$\chi^{2}$ (for mortality rate in potentially viable babies with RDS who tolerated THAM, and those who did not; using Yates' correction) = 1.89; $0.20<\mathrm{p}<0.10$, NS.

*Includes one baby who died at 6 weeks. 
TABLE II

Data on 9 Potentially Viable Babies with Other Diagnoses Than RDS

\begin{tabular}{|c|c|c|c|c|c|}
\hline & No. & $\begin{array}{c}\text { Birthweight } \\
\text { (g.) }\end{array}$ & $\begin{array}{l}\text { Gestational } \\
\text { Age (wk.) }\end{array}$ & Diagnosis & Comment \\
\hline Babies tolerating THAM & $\begin{array}{l}1 \\
2 \\
3 \\
4 \\
5\end{array}$ & $\begin{array}{l}1940 \\
1940 \\
3350 \\
3400 \\
3380\end{array}$ & $\begin{array}{l}37 \\
34 \\
39 \\
40 \\
41\end{array}$ & $\begin{array}{l}\text { Pulmonary haemorrhage; } \\
\text { hypoglycaemia } \\
\text { Pneumococcal } \\
\text { septicaemia } \\
\text { Birth asphyxia } \\
\text { Birth asphyxia } \\
\text { Birth asphyxia }\end{array}$ & $\begin{array}{l}\text { Alive and well; apnoeic attack before } \\
\text { THAM administered } \\
\text { Died; one of twins; other twin and } \\
\text { mother also had pneumococcal } \\
\text { septicaemia but survived } \\
\text { Died; necropsy, massive pulmonary } \\
\text { haemorrhage } \\
\text { Died; necropsy, meconium aspiration } \\
\text { Died; necropsy, pulmonary and subdural } \\
\text { haemorrhage }\end{array}$ \\
\hline Babies apnoeic after THAM & $\begin{array}{l}6 \\
7 \\
8\end{array}$ & $\begin{array}{r}820 \\
1620 \\
3240\end{array}$ & $\begin{array}{l}28 \\
39 \\
\\
39\end{array}$ & $\begin{array}{l}\text { Apnoea of prematurity } \\
\text { Birth asphyxia; } \\
\text { hypoglycaemia } \\
\text { Birth asphyxia } \\
\text { Hydrops fetalis }\end{array}$ & $\begin{array}{l}\text { Alive and well } \\
\text { Died; necropsy refused } \\
\text { Died after prolonged period of artificial } \\
\text { respiration; necropsy, pneumonia, } \\
\text { obstructed airways; infarction and } \\
\text { perforation of colon } \\
\text { Died; necropsy, severe erythroblastosis }\end{array}$ \\
\hline
\end{tabular}

TABLE III

\section{Cause of Death Ascertained at Necropsy}

\begin{tabular}{l|c}
\hline & No. \\
\hline Non-viable infants & 26 \\
Previable fetuses & 16 \\
Major congenital malformations & 10 \\
Potentially viable infants & 38 \\
Hyaline membrane disease (HMD) & 32 \\
HMD with intraventricular haemorrhage & 16 \\
HMD alone & 6 \\
HMD with obstructed airway on ventilator & $4{ }^{\star}$ \\
HMD with subdural haemorrhage & 3 \\
HMD with haemolytic disease of newborn & 2 \\
HMD with septicaemia & 1 \\
Intrapartum anoxia without HMD & 4 \\
Hydrops fetalis & 1 \\
Pneumococcal septicaemia & 1 \\
Necropsy refused & 2 \\
\hline Total & 66 \\
\hline
\end{tabular}

«Two of these babies also had an intraventricular haemorrhage, and one of them was the baby dying at 6 weeks. either a subsequent or a previous episode of $\vec{\nabla}$ respiratory depression after THAM administration; 3 of these 6 had RDS.

It is the 65 babies suffering from RDS that will $\vec{\varphi}$ be discussed in the rest of this paper.

The babies with RDS who became apnoeic after THAM were compared with those who did not, with respect to the following parameters.

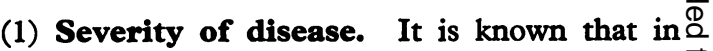
babies with RDS the initial $\mathrm{P}_{\mathrm{a}} \mathrm{O}_{2}$ in $100 \%$ oxygen $\overrightarrow{\overrightarrow{0}}$ during the first 6 hours of life-the so-called 3 'hyperoxia' test-provides a good indication of the severity of the disease and the ultimate prognosis? (Boston, Geller, and Smith, 1966; Roberton et al., 1968). Those who can achieve a $\mathrm{P}_{\mathrm{a}} \mathrm{O}_{2}$ of $100 \mathrm{~mm}$. ? $\mathrm{Hg}$ have a mortality of about $25 \%$; those who을 cannot have mortality of about $75 \%$. These data. were available on 43 out of 65 babies. Table IVO shows that there is no obvious difference in the

TABLE IV

Prognosis Assessed Before 6 Hours with Hyperoxia Test in Two Groups of Babies

\begin{tabular}{|c|c|c|c|c|c|c|c|c|c|c|c|c|}
\hline & \multicolumn{6}{|c|}{ THAM Tolerated } & \multicolumn{6}{|c|}{ Apnoea After THAM } \\
\hline & \multicolumn{3}{|c|}{ No Previous Apnoea } & \multicolumn{3}{|c|}{$\begin{array}{l}\text { Previous Spontaneous } \\
\text { Apnoeic Attack }\end{array}$} & \multicolumn{3}{|c|}{ No Previous Apnoea } & \multicolumn{3}{|c|}{$\begin{array}{l}\text { Previous Spontaneous } \\
\text { Apnoeic Attack }\end{array}$} \\
\hline & Alive & Dead & Total & Alive & Dead & Total & Alive & Dead & Total & Al:ve & Dead & Total \\
\hline $\begin{array}{l}\text { 'Good Prognosis' } \\
\text { i.e. } \mathrm{P}_{\mathrm{a}} \mathrm{O}_{2} \geqslant 100 \mathrm{~mm} \text {. } \mathrm{Hg} \text { in } \\
100 \% \mathrm{O}_{2} \text { before } 6 \text { hours } \\
\text { 'Bad Prognosis' } \\
\text { i.e. } \mathrm{P}_{\mathrm{a}} \mathrm{O}_{2}<100 \mathrm{~mm} \text {. } \mathrm{Hg} \text { in } \\
100 \% \mathrm{O}_{2} \text { before } 6 \text { hours }\end{array}$ & 12 & 6 & 14 & 3 & - & 2 & - & 一 & 1 & - & - & 一 \\
\hline
\end{tabular}


prognosis on the hyperoxia test of the four groups of babies shown. In particular there is no difference in prognosis assessed by the hyperoxia test between the group of babies who tolerated THAM and those who did not; there were more 'good' prognosis babies in the group who deteriorated after THAM. The blood gas tensions immediately before the drug was injected were very similar both in those babies who tolerated the drug and in those who did not (Table V).

\section{TABLE V}

Mean Blood Gas Tensions Immediately Preceding Injection of Alkali

\begin{tabular}{l|c|c|c}
\hline & $\begin{array}{c}\text { Babies } \\
\text { Becoming } \\
\text { Apnoeic } \\
\text { After THAM }\end{array}$ & $\begin{array}{c}\text { Babies } \\
\text { Tolerating } \\
\text { THAM }\end{array}$ & $\begin{array}{c}\text { Babies } \\
\text { Receiving } \\
\text { Sodium } \\
\text { Bicarbonate }\end{array}$ \\
\hline $\mathrm{P}_{\mathrm{g} \mathrm{O}_{2} \mathrm{~mm} . \mathrm{Hg}}$ & 60 & 66 & 85 \\
$\mathrm{SEM}$ & $9 \cdot 3$ & $2 \cdot 9$ & $7 \cdot 4$ \\
\hline $\mathrm{P}_{\mathrm{g} \mathrm{CO}_{2} \mathrm{~mm} . \mathrm{Hg}}$ & 58 & 59 & 43 \\
$\mathrm{SEM}$ & $4 \cdot 7$ & $1 \cdot 6$ & $2 \cdot 2$ \\
\hline$p \mathrm{H}$ & $7 \cdot 12$ & $7 \cdot 16$ & $7 \cdot 18$ \\
$\mathrm{SEM}$ & $0 \cdot 04$ & $0 \cdot 01$ & 0.01 \\
\hline
\end{tabular}

SEM, standard error of the mean.

(2) Incidence of previous apnoeic attacks. There was a significantly greater incidence of spontaneous apnoeic attacks in those babies who became apnoeic after THAM compared with those babies who tolerated the drug (Table VI). All 6 babies who had had spontaneous apnoeic attacks, but who tolerated THAM, survived the neonatal period, though one did die at 6 weeks of age from the effects of tracheal stenosis acquired during prolonged intubation and IPPR. However, of the 6 babies who had had spontaneous apnoeic attacks but who did not tolerate THAM 4 died. The apnoeic attacks that occurred spontaneously were presumably more severe in the babies who had tolerated THAM than in those babies who had not, since all 6 in the first group required IPPR

\section{TABLE VI}

Incidence of Previous Spontaneous Apnoeic Attacks in Babies with RDS Who Received THAM

\begin{tabular}{l|c|c}
\hline & $\begin{array}{c}\text { Babies becoming } \\
\text { Apnoeic After } \\
\text { THAM }\end{array}$ & $\begin{array}{c}\text { Babies } \\
\text { Tolerating } \\
\text { THAM }\end{array}$ \\
\hline $\begin{array}{l}\text { Previous spontaneous } \\
\text { apnoea }\end{array}$ & 6 & 6 \\
No previous apnoea & 5 & 48 \\
\hline
\end{tabular}

$\chi^{2}$ (with Yates correction) $=8 \cdot 71 ; \mathrm{p}<0.01$. following apnoea, whereas no baby required IPPR in the second group, all their apnoeic attacks responding to peripheral stimulation and pharyngeal suction. In the 12 babies with spontaneous apnoeic episodes, there was no difference in the prognosis on the hyperoxia test at 6 hours between those who subsequently tolerated THAM and those who did not.

(3) Age at which apnoeic episodes occurred. It is generally believed that apnoeic attacks occurring in the first 24 hours of life in a baby with RDS carry a much worse prognosis than attacks occurring later. The relevant data on the babies in this series are shown in Table VII. As pointed out earlier, the 6 babies who tolerated THAM after a previous spontaneous apnoeic attack all survived the neonatal period; 6 of the 11 babies in whom THAM caused a deterioration had had spontaneous apnoeic attacks, 2 before, 4 after, 24 hours of age. The numbers are too small for statistical analysis, but there is nothing to suggest that the babies who deteriorated either spontaneously or after THAM before 24 hours of age, had a poorer ultimate outlook than those who deteriorated after 24 hours of age. There was no difference in prognosis assessed by $\mathrm{P}_{\mathrm{a}} \mathrm{O}_{2}$ in $100 \%$ oxygen by 6 hours, between those babies who were to deteriorate before or after 24 hours of age, either spontaneously or after injection of THAM.

(4) Death rate. It is important to assess whether the death rate in babies becoming apnoeic after THAM is higher than in babies who tolerated the drug. In Table $I$ it can be seen that the

TABLE VII

Age at Which Spontaneous Apnoea and Apnoea After THAM Occurred (Babies with RDS)

\begin{tabular}{|c|c|c|c|}
\hline & \multicolumn{2}{|c|}{ Apnoea after THAM } & \multirow{2}{*}{$\begin{array}{c}\text { No } \\
\text { Apnoea } \\
\text { After } \\
\text { THAM }\end{array}$} \\
\hline & $\begin{array}{l}\text { Apnoea With } \\
\text { THAM Occur- } \\
\text { ring Before } \\
24 \text { hours }\end{array}$ & $\begin{array}{l}\text { Apnoea With } \\
\text { THAM Occur- } \\
\text { ring After } \\
24 \text { hours }\end{array}$ & \\
\hline $\begin{array}{l}\text { Spontaneous apnoeic } \\
\text { attack occurring } \\
\text { before } 24 \text { hours } \\
\text { Spontaneous apnoeic } \\
\text { attack occurring } \\
\text { after } 24 \text { hours } \\
\text { No previous } \\
\text { spontaneous } \\
\text { apnoea }\end{array}$ & $\begin{array}{l}2(1) \\
- \\
3(0)\end{array}$ & $\begin{array}{l}4(1) \\
2(1)\end{array}$ & $\begin{array}{l}4(4) t \\
2(2)\end{array}$ \\
\hline
\end{tabular}

Figures in parentheses are survivors.

$\star$ There were 48 babies (Table VI) who did not have spontaneous apnoea and also tolerated THAM.

fIncludes one baby who died at 6 weeks. 
difference in the over-all death rate between babies with RDS in the two groups is not statistically significant. In Table VIII these two groups have been further subdivided into those who had had previous spontaneous apnoeic attacks, and those who had not. There was no significant difference in the birthweights, gestational ages, and blood gas tensions just before THAM was injected, between the babies in the four different subgroups in Table VIII. It can be seen that having suffered a spontaneous apnoeic attack, irrespective of whether THAM was subsequently tolerated or not does not seem to affect the mortality rate. However, only 1 baby survived out of the 5 who had their first apnoeic attack after THAM injection. There was no difference in any of the following 9 parameters between those babies who tolerated THAM and those who did not.

\section{TABLE VIII}

Mortality Rates in the Different Groups of Babies With RDS

\begin{tabular}{l|c|c|c|c}
\hline & \multicolumn{2}{|c|}{ THAM Tolerated } & \multicolumn{2}{|c|}{ Apnoea After THAM } \\
\cline { 2 - 4 } & $\begin{array}{c}\text { No } \\
\text { Previous } \\
\text { Apnoea }\end{array}$ & $\begin{array}{c}\text { Previous } \\
\text { Spontaneous } \\
\text { Apnoeic } \\
\text { Attack }\end{array}$ & $\begin{array}{c}\text { No } \\
\text { Previous } \\
\text { Apnoea }\end{array}$ & $\begin{array}{c}\text { Previous } \\
\text { Spontaneous } \\
\text { Apnoeic } \\
\text { Attack }\end{array}$ \\
\hline $\begin{array}{l}\text { Alive } \\
\text { Dead }\end{array}$ & 24 & $6^{\star}$ & 1 & 2 \\
\hline
\end{tabular}

*Includes one baby who died at 6 weeks.

(5) Birthweight (Table IX); (6) Gestational age (Table IX); (7) Route of injection (Table X); (8) Age of baby in hours when drug injected (Table XI); (9) Total Volume of drug administered during the illness (Table XII); (10) Volume of each injection (Table XIII); (11) Blood gas tensions $\left(\mathrm{P}_{\mathrm{a}} \mathrm{O}_{2}, p \mathrm{H}\right.$, and $\left.\mathrm{P}_{\mathrm{a}} \mathrm{CO}_{2}\right)$ immediately before drug injected (Table V); (12) Strength of Injection $(3.6 \%$ or $7 \cdot 0 \%$ ) (Table XIV); and (13) IVH rate (Table XV). In particular, the means of the blood gas tensions immediately preceding the injection of THAM were very similar (Table V).

If we compare the above parameters in babies who received sodium bicarbonate, against all babies receiving THAM, there was no significant difference between the two groups for parameters 3 to 10 inclusive, apart from larger volumes of bicarbonate being given at each injection (Table XIII). The incidence of previous apnoeic attacks in babies receiving bicarbonate (7 out of 23 or $30 \%$ ) is intermediate between the incidence of babies tolerating and not tolerating THAM (Table VI)-though not significantly different from either. There was also a higher proportion of good prognosis babies (parameter 1) amongst those: receiving sodium bicarbonate (11 out of 15 withs data available at 6 hours), compared with babies who received THAM (21 out of 43 with dato available at 6 hours), though again the difference is not statistically significant. The blood gas tensionsD immediately before the drug was given were, how 0 ever, significantly different (Table V). The babies who received sodium bicarbonate had a significantly $\vec{D}$ higher $\mathrm{P}_{\mathrm{a}} \mathrm{O}_{2}$ and lower $\mathrm{P}_{\mathrm{a}} \mathrm{CO}_{2}$ than those receiving THAM; their $p \mathrm{H}$ values were, however, verys similar. This indicates that the babies whou received sodium bicarbonate had a less severẹ respiratory illness than those receiving THAM er This finding was inevitable, as it had been our practice to administer sodium bicarbonate only tọ those babies with a primarily metabolic acidosis. N

The IVH rate (parameter 13) (Table XV) in babies receiving sodium bicarbonate and THAME is difficult to compare, as only 7 babies received sodium bicarbonate without THAM and none of

TABLE IX

Mean Birthweight and Gestational Age of Differento Groups

\begin{tabular}{|c|c|c|}
\hline & $\begin{array}{l}\text { Birthweight } \\
\text { (g.) }\end{array}$ & $\begin{array}{c}\text { Gestational } \\
\text { Age (wk.) }\end{array}$ \\
\hline $\begin{array}{l}\text { THAM tolerated } \\
\text { Apnoea after THAM } \\
\mathrm{NaHCO}_{3}\end{array}$ & $\begin{array}{c}1902 \\
\text { SEM } 66 \\
1803 \\
\text { SEM } 156 \\
2015 \\
\text { SEM } 114\end{array}$ & $\begin{array}{c}325 / 7 \\
\text { SEM } 3 \cdot 4 \text { days } \\
334 / 7 \\
\text { SEM } 6 \cdot 1 \text { days } \\
341 / 7 \\
\text { SEM } 4 \cdot 6 \text { days }\end{array}$ \\
\hline
\end{tabular}

TABLE X

Number of Injections of Alkali Given by Each Route

\begin{tabular}{|c|c|c|c|}
\hline Route of Injection & $\begin{array}{l}\text { THAM } \\
\text { Tolerated }\end{array}$ & $\begin{array}{c}\text { Apnoea } \\
\text { After } \\
\text { THAM }\end{array}$ & 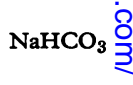 \\
\hline $\begin{array}{l}\text { Umbilical arterial catheter } \\
\text { Umbilical venous catheter }\end{array}$ & $\begin{array}{r}17 \\
111\end{array}$ & $\begin{array}{l}2 \\
9\end{array}$ & $\begin{array}{r}5 \\
29\end{array}$ \\
\hline
\end{tabular}

TABLE XI

Age at Injection of Each Dose of Alkali to the Threen Groups of Babies

\begin{tabular}{|c|c|c|c|}
\hline $\begin{array}{c}\text { Age at } \\
\text { Injection (hr.) }\end{array}$ & $\begin{array}{c}\text { THAM } \\
\text { Tolerated }\end{array}$ & $\begin{array}{c}\text { Apnoea After } \\
\text { THAM }\end{array}$ & $\mathrm{NaHCO}_{3}$ \\
\hline $\begin{aligned} & 66 \\
& 6-<24 \\
\geqslant & 24\end{aligned}$ & $\begin{array}{l}39 \\
42 \\
47\end{array}$ & $\begin{array}{l}3 \\
3 \\
5\end{array}$ & $\begin{array}{r}6 \\
13 \\
15\end{array}$ \\
\hline
\end{tabular}

$\chi^{2}$ (for time of injection of THAM versus time of injection of $\left.\mathrm{NaHCO}_{3}\right)=2.37 ; 0.5<\mathrm{p}<0.3 \mathrm{NS}$. 
TABLE XII

Total Volume of Drug Administered to Each Group of Babies

\begin{tabular}{c|c|c|c}
\hline $\begin{array}{c}\text { Total Volume } \\
\text { THAM } \\
\begin{array}{c}\text { Administered } \\
\text { (ml.) }\end{array}\end{array}$ & $\begin{array}{c}\text { THAM } \\
\text { Tolerated }\end{array}$ & $\begin{array}{c}\text { Apnoea After } \\
\text { THAM }\end{array}$ & NaHCO $_{3}$ \\
\hline$\leqslant 15$ & 33 & 8 & 20 \\
$>15$ & 21 & 3 & 3 \\
\hline
\end{tabular}

$\chi^{2}$ (for THAM tolerated versus $\mathrm{NaHCO}_{3}$ administered, with Yates' correction) $=3.63 ; 0.10<\mathrm{p}<0.05$ NS.

$\chi^{2}$ (for THAM tolerated versus apnoea after THAM, with Yates' correction) $=0.24 ; 0.7<p<0.5$ NS.

\section{TABLE XIII}

Volume of Each Injection of Alkali in Different Groups of Babies

\begin{tabular}{c|c|c|c}
\hline $\begin{array}{c}\text { Size of Each } \\
\text { Injection (ml.) }\end{array}$ & $\begin{array}{c}\text { THAM } \\
\text { Tolerated }\end{array}$ & $\begin{array}{c}\text { Apnoea After } \\
\text { THAM }\end{array}$ & NaHCO $_{3}$ \\
\hline$<10$ & 103 & 8 & 19 \\
$\geqslant 10$ & 25 & 3 & 15 \\
\hline
\end{tabular}

$\chi^{2}$ (for THAM tolerated versus $\mathrm{NaHCO}_{3}$ using Yates' correction) $=7.56 ; 0.001<\mathrm{p}<0.01$

$\chi^{2}$ (for THAM tolerated versus apnoea after THAM, using Yates' correction) $=0.05 ; 0.9<p<0.8$ NS.

TABLE XIV

Number of Babies Receiving the Two Strengths of THAM

\begin{tabular}{c|c|c}
\hline $\begin{array}{c}\text { Strength of THAM } \\
(\%)\end{array}$ & THAM Tolerated & Apnoea After THAM \\
\hline 3.6 & 69 & 3 \\
7.0 & 59 & 8 \\
\hline
\end{tabular}

$\chi^{2}=1.92 ; 0.2<p<0.1$ NS.

TABLE XV

Number of Babies with IVH After Treatment with Alkali

\begin{tabular}{l|c|c|c|c}
\hline & $\begin{array}{c}\text { THAM } \\
\text { Tolerated }\end{array}$ & $\begin{array}{c}\text { Apnoea After } \\
\text { THAM }\end{array}$ & $\begin{array}{c}\mathrm{NaHCO}_{3} \\
\text { and THAM } \\
\text { Given }\end{array}$ & $\begin{array}{c}\text { Only } \\
\mathrm{NaHCO}_{3} \\
\text { Given }\end{array}$ \\
\hline No IVH & 40 & 7 & 18 & 7 \\
IVH & 14 & 4 & 5 & - \\
\hline
\end{tabular}

$\chi^{2}$ (for IVH rate in THAM-tolerated group versus $\mathrm{NaHCO}_{3}$ only, using Yates' correction) $=1.55 ; 0.3<\mathrm{p}<0.2$ NS.

these had an IVH. There was, however, no significant difference in the IVH rate in those babies who received both sodium bicarbonate and THAM, compared with those who received THAM alone. Though there was no significant difference in the IVH rate-in babies who became apnoeic after THAM and those who did not (parameter 13), or in the apnoea rate of babies receiving $3.6 \%$ THAM or $7.0 \%$ THAM (parameter 12), there was a significantly higher incidence of IVH in those babies who received $7 \cdot 0 \%$ THAM compared with those who received $3.6 \%$ THAM (Table XVI).

\section{TABLE XVI}

Incidence of IVH in Babies with RDS Who Received THAM

\begin{tabular}{c|c|c}
\hline $\begin{array}{c}\text { Strength of } \\
\text { THAM (\%) }\end{array}$ & $\begin{array}{c}\text { Babies with } \\
\text { IVH }\end{array}$ & $\begin{array}{c}\text { Babics with } \\
\text { No Haemorrhage }\end{array}$ \\
\hline 3.6 & 2 & 24 \\
7.0 & 16 & 23 \\
\hline
\end{tabular}

$\chi^{2}$ (with Yates' correction) $=7.69 ; \mathrm{p}<0.01$.

The physical characteristics of the solutions injected seems unlikely to be important in the aetiology of the apnoea, or of the IVH. The THAM solutions were either 0.3 molar or 0.58 molar, but the sodium bicarbonate solutions were usually twice molar-much more hypertonic than the THAM solutions. Bearing in mind the dangers of intravenous hyperosmolar solutions, which include intracerebral haemorrhage, and of exceeding an infusion rate of $25 \mathrm{mOsm}$. $/ \mathrm{kg}$. body water $/ 4$ hours (Finberg, 1967), we found 2 babies out of the 65 who exceeded this. At the time of receiving the osmolar load, both the babies were already apnoeic and being artificially ventilated. The most significant feature was that the majority of the osmoles administered to these babies were in the form of sodium bicarbonate-yet neither apnoea nor IVH seemed to be a feature of sodium bicarbonate being given to other babies. One of these babies had an IVH.

\section{Discussion}

THAM has three major theoretical advantages over sodium bicarbonate: it is capable of correcting a hypercapnic acidosis directly; it is just as efficient at correcting a metabolic acjdosis (Ligou and Nahas, 1960; Nahas, 1963) in the extracellular fluid and more efficient at correcting $\mathrm{CSF} p \mathrm{H}$, and the intracellular component of a metabolic acidosis (Robin, Wilson, and Bromberg, 1961; Holmdahl et al., 1961); and it achieves these actions without adding sodium ions to the circulation. Some workers, however, have shown that sodium bicarbonate corrects intracellular $p \mathrm{H}$ just as effectively as THAM (Adler, Roy, and Relman, 1965), or even better (Irvine and Dow, 1966). Rapid correction of intracellular and CSF $p H$ is not necessarily 
beneficial. It has been suggested that the apnoea which followed THAM administration in hypercapnic acidosis is due to the too rapid correction of the $p \mathrm{H}$ around and within the respiratory centre, thereby decreasing the drive to inspiration (Katz et al., 1963). THAM is known in experimental animals and adult man to be very effective at correcting a hypercapnic acidosis by increasing the $p \mathrm{H}$ and bicarbonate and lowering the $\mathrm{P}_{\mathrm{a}} \mathrm{CO}_{2}$ (Brown et al., 1961; Epstein, Nahas, and Mark, 1961). In normal adult human volunteers (Berman, O'Connor, and Luchsinger, 1960) and in adult humans in respiratory failure with a raised $\mathrm{P}_{\mathrm{a}} \mathrm{CO}_{2}$, THAM definitely causes respiratory depression (Luchsinger, 1961; Swanson, 1960). In our babies the doses of THAM given were too small to have any direct effect on the $\mathrm{P}_{\mathrm{a}} \mathrm{CO}_{2}$ values. This action of THAM is due to combination of 1 mole THAM with 1 mole $\mathrm{CO}_{2}$ (Fig.). Thus $5 \mathrm{ml}$. 3.6\% THAM contains approximately $1.5 \mathrm{mM}$. THAM which will remove $1.5 \mathrm{mM}$. $\mathrm{CO}_{2}$ from the circulation: this can be calculated as equivalent to the amount of $\mathrm{CO}_{2}$ evolved in approximately 2 minutes in a sick neonate weighing $2000 \mathrm{~g}$. It is also becoming apparent that prolonged high $\mathrm{P}_{\mathrm{a}} \mathrm{CO}_{2}$ values are compatible with survival, provided that the $p H$ is controlled (Adamson et al., 1968). In the babies described by Gupta et al. (1967), the $\mathrm{P}_{\mathrm{a}} \mathrm{CO}_{2}$ values improved concurrently with the $p \mathrm{H}$ and $\mathrm{P}_{\mathrm{a}} \mathrm{O}_{2}$ after injection of THAM, presumably due to improvement in pulmonary perfusion, and correction of the respiratory acidosis at source.

The problem of a sodium load does not seem to arise in practice. In our babies it is only in the full-term babies who have RDS mimicking cyanotic congenital heart disease (Roberton, Hallidie-Smith, and Davis, 1967) that heart failure requiring and benefiting from digoxin is seen, and these babies usually need very little correction of acidaemia. No baby described in the present paper who received sodium bicarbonate developed heart failure.

THAM is also known to increase the serum potassium (Epstein et al., 1961), and though this was not measured routinely it may have played a part in the two cardiac arrests that occurred during THAM administration to our babies. The known metabolic effect of THAM to lower the blood glucose (Bennett and Tarail, 1961) was not detected. We have not seen any cases of liver necrosis (Goldenberg, Wiegenstein, and Hopkins, 1968; Nahas, 1968).

In this series respiratory depression coincident with THAM administration took place in 17 out of 100 babies treated at Hammersmith Hospital in the years 1965--1967. The series described by
Gupta et al. (1967) comprised babies also treate $\frac{\rho}{T^{2}}$ at Hammersmith in the years 1963-1965. Of their. 23 babies who received THAM only one becam $\overrightarrow{\vec{E}^{*}}$ immediately apnoeic. The records have been scrutinized to confirm that this was indeed the case There was no obvious difference in the method ofs. administration of THAM between these tw periods, except that in the earlier series THAM? was more frequently administered by the arteria route, and only given as the $3 \cdot 6 \%$ solution.

From our findings there is little doubt that the hypercapnic newborn baby may respond to THANE by developing respiratory depression in a similam way to the adult human and experimental animaho From the data we have available, the babies whis deteriorated in this way did not seem to have had a more severe form of the disease, as judged by the hyperoxia test, and their blood gas tensions imi mediately before the THAM was administered? However, they had had significantly moro spontaneous apnoeic attacks before THAM administration.

It is difficult to assess whether THAM, by causing. apnoea, has increased the death rate, either directly or by increasing the IVH rate. Of 54 babies who tolerated THAM, 30 survived; of 11 babies whe did not tolerate THAM, only 3 survived, but these differences are not statistically significant (Table I) There was a surprisingly high mortality in all the 'good prognosis' babies in the series $(12 / 21,57 \%$ ) but this was not further increased in those babies who deteriorated after THAM. The high mortality i babies within the 'good prognosis group' suggest that the babies in this group who require $p$ 艮 correction have a worse prognosis than those who do not. It is a well-established fact that low $p \mathrm{~F}^{\mathrm{P}}$ in its own right is a bad prognostic finding, an $\frac{\mathrm{p}}{\mathrm{g}}$ Stahlman et al. (1967) include $\mathrm{pH}$ among their important determinants for assessing survival.

The interpretation of the higher IVH rate in babies given $7 \%$ THAM is also difficult, particularly as the actual cause of IVH is unknown? Milder cases of RDS may be less likely to sustaid an IVH and are certainly more likely to receive. only the $3.6 \%$ solution, whereas the more criticalls ill baby with severe acidaemia is more likely to be treated with the stronger $(7 \%)$ solution and independently, may be more likely to have an IVH

Because of the dramatic improvement seen in some cases after the injection of THAM, it has been suggested that the drug may have a directlip beneficial effect on the pulmonary hypertension and hypoperfusion in RDS, and thereby, if adminis: tered early in the course of the disease, effect permanent improvement in the pulmonary circula 
tion. In experimental animals, THAM is known to be of no benefit in the pulmonary hypertension of hypoxia (Bergofsky et al., 1961), though it will improve the pulmonary hypertension of acidaemia from any cause (Ligou et al., 1961). It has recently been shown that similar dramatic responses to those seen by Gupta et al. (1967) after THAM have followed sodium bicarbonate administration (Russell and Cotton, 1968).

One can draw no meaningful comparisons of death and IVH rates between the babies with RDS receiving THAM or sodium bicarbonate, as the two groups of babies were very different in terms of their prognosis on blood gas tensions at 6 hours of age, and their physiological derangement when alkali was injected. However, no baby deteriorated after injection of sodium bicarbonate, and in fact apnoea is not a recognized complication of its administration.

\section{Conclusions}

The incidence of respiratory depression of $17 \%$ after administration of THAM to babies with RDS suggests that the use of this drug to correct acidaemia in neonatal respiratory failure should be reevaluated, comparing it with the use of sodium bicarbonate in a control series, and, meanwhile, THAM should be used only in hospital units with facilities for prolonged mechanical ventilation of the newborn. (Of the 3 out of the 11 babies with RDS who survived THAM-induced apnoea, 2 required artificial ventilation for many hours.) It is important to realize that the respiratory depressant action of THAM is not limited to babies with RDS. 4 of the 9 babies listed in Table II, who were suffering from other disease processes, also become apnoeic after its administration.

THAM may still have a place in the management of certain respiratory problems in the neonate. In the rare baby who is being artificially ventilated without satisfactory control of the $\mathrm{P}_{\mathrm{a}} \mathrm{CO}_{2}$, THAM appears to be the drug of choice. THAM may also be preferable in the resuscitation of the asphyxiated newborn where IPPR is being used. The rapid correction of intracellular $p \mathrm{H}$ within the respiratory centre may initiate gasping and then regular respiration which had not previously been possible in the presence of a severe depression of the extracellular, intracellular, and CSF $p H$ (Dawes, 1968).

The fact that equimolar doses of THAM are less effective buffers at body $p \mathrm{H}$ than doses of sodium bicarbonate (Nahas, 1963; Bleich and Schwartz, 1966); the fact that these more dilute solutions of THAM probably cause more apnoea; the fact that THAM may cause more IVH; and the fact that the more concentrated solutions of sodium bicarbonate seem to be well tolerated, suggest that sodium bicarbonate may well prove to be the base of choice in the routine treatment of acidaemia in the newborn baby with RDS.

Though the superiority of sodium bicarbonate is not conclusively proved in this study, there is a case for carrying out a carefully controlled trial of the use of the two agents in the respiratory distress syndrome.

I thank Professor J. P. M. Tizard and Dr. R. J. Robinson for their help in the preparation of this manuscript; Professor J. A. Davis for his advice and criticism; the resident medical staff of the Neonatal ward, Hammersmith Hospital, upon whose observations and blood gas analyses this paper was based; and Sisters M. E. Castle and J. E. James and the nursing staff of the neonatal unit who looked after the babies.

This paper was presented to a meeting of the Paediatric Research Society at Bristol on 19 October 1968.

\section{REFERENCES}

Adamson, T. M., Collins, L. M., Dehan, N., Hawker, J. M., Reynolds, E. O. R., and Strang, L. B. (1968). Mechanical ventilation in the newborn infant with respiratory failure. Lancet, 2, 227.

Adler, S., Roy, A., and Relman, A. S. (1965). Intracellular acid base regulation. I. The response of muscle cells to changes in $\mathrm{CO}_{2}$ tension or extracellular bicarbonate concentration. Fournal of Clinical Investigation, 44, 8.

Bennett, T. E., and Tarail, R. (1961). The hypoglycemic activity of 2-amino-2-hydroxymethyl-1, 3-propanediol. Annals of the New York Academy of Sciences, 92, 651.

Bergofsky, E. H., Lehr, D. E., Tuller, M. A., Rigatto, M., and Fishman, A.P. (1961). The effects of acute alkalosis and acidosis on the pulmonary circulation. Annals of the NewYork Academy of Sciences, 92, 627.

Berman, L. B., O'Connor, T. F., and Luchsinger, P. C. (1960). Carbon-dioxide buffering in man. Fournal of Applied Physio$\log y, 15,393$.

Bleich, H. L. and Schwartz, W. B. (1966). Tris buffer (THAM). An appraisal of its physiologic effects and clinical usefulness. New England Fournal of Medicine, 274, 782.

Boston, R. W., Geller, F., and Smith, C. A. (1966). Arterial blood gas tensions and acid-base balance in the management of the respiratory distress syndrome. Fournal of Pediatrics, 68, 74.

Brown, E. S., Greene, D. G., Elam, J. O., Evers, J. L., Bunnell, I. L., and Lowe, H. J. (1961). Effects of 2-amino-2-hydroxymethyl-1, 3-propanediol on $\mathrm{CO}_{2}$ elimination and production in normal man. Annals of the New York Academy of Sciences, $92,508$.

Dawes, G. S. (1968). Foetal and Neonatal Physiology, p. 149. Year Book Medical Publishers, Chicago.

Epstein, R. M., Nahas, G. G., and Mark, L. C. (1961). Circulatory changes following rapid correction of severe hypercapnic acidosis by 2-amino-2-hydroxymethyl-1, 3-propanediol. Annals of the New York Academy of Sciences, 92, 500.

Finberg, L. (1967). Dangers to infants caused by changes in osmolal concentration. Pediatrics, 40, 1031.

Goldenberg, V. E., Wiegenstein, L., and Hopkins, G. B. (1968). Hepatic injury associated with tromethamine. Fournal of the American Medical Association, 205, 81.

Gupta, J. M., Dahlenburg, G. W., and Davis, J. A. (1967). Changes in blood gas tensions following administration of amine buffer THAM to infants with the respiratory distress syndrome. Archives of Disease in Childhood, 42, 416.

Holmdahl, M. H., Nahas, G. G., Hassam, D., and Verosky, M. (1961). Acid-base changes in the C.S.F. following rapid changes in the bicarbonate/carbonic acid ratio in the blood. Annals of the New York Academy of Sciences, 92, 520. 
Hutchison, J. H., Kerr, M. M., Douglas, T. A , Inall, J. A., and Crosbie, J. C. (1964). A therapeutic approach in 100 cases of the respiratory distress syndrome of the newborn infant. Pediatrics, 33, 956.

Irvine, R. O. H., and Dow, J. (1966). Sodium bicarbonate, sodium lactate and Tris. in the treatment of metabolic acidosis: effects on intracellular $\mathrm{pH}$ and electrolyte content of voluntary muscle. Metabolism: Clinical and Experimental, 15, 1011.

Katz, R. L., Ngai, S. H., Nahas, G. G., and Wang, S. C. (1963). Relationship between acid-base balance and the central respiratory mechanisms. American fournal of Physiology, 204, 867.

Ligou, J. C., Le Tallec, Y., Bernadet, P., Broue, A., and Calazel, P. (1961). Effects of 2-amino-2-hydroxymethyl-1, 3-propanediol on the pulmonary hypertension of hypercephalic acidosis. Annals of the New York Academy of Sciences, 92, 617.

-, and Nahas, G. G. (1960). Comparative effects of acidosis induced by acid infusion and $\mathrm{CO}_{2}$ accumulation. American fournal of Physiology, 198, 1201.

Luchsinger, P. C. (1961). The use of 2-amino-2-hydroxymethyl1, 3-propanediol in the management of respiratory acidosis. Annals of the New York Academy of Sciences, 92, 743.

Nahas, G. G. (1963). The clinical pharmacology of THAM. Clinical Pharmacology and Therapeutics, 4, 784.

- (1968). Hepatic injury related to tromethamine. Fournal of the American Medical Association, 206, 1793.

Oppé, T. E., Priestley, B. L., and Redstone, D. (1965). Metabolic changes in the infant with respiratory failure. Pediatric Clinics of North America, 12, 723.

Reynolds, E. O. R., Roberton, N. R. C., and Wigglesworth, J. S. (1968). Hyaline membrane disease, respiratory distress and surfactant deficiency. Pediatrics, 42, 758.

Roberton, N. R. C., Gupta, J. M., and Dahlenburg, G. W., and Tizard, J. P. M. (1968). Oxygen therapy in the newborn. Lancet, 1, 1323.
—, Hallidie-Smith, K. A., and Davis, J. A. (1967). Severe respiratory distress syndrome mimicking cyanotic heart-disease $\frac{\overline{2}}{2}$ in term babies. Lancet, 2, 1108.

Robin, E. D., Wilson, R. J., and Bromberg, P. A. (1961). Intracellular acid-base relations and intracellular buffers. Annals of the New York Academy of Sciences, 92, 539.

Rudolph, A. J., and Smith, C. A. (1960). Idiopathic respiratory distress syndrome of the newborn. Fournal of Pediatrics, 57, 905.

Russell, G., and Cotton, E. K. (1968). Effects of sodium bicarbonate by rapid injection and of oxygen in high concentration in respiratory distress syndrome of the newborn. Pediatrics, 41, 1063.

Stahlman, M. T., Battersby, E. J., Shepard, F. M., and Blankenship, W. J. (1967). Prognosis in hyaline-membrane disease. Use $\vec{\omega}$ of a linear-discriminant. New England fournal of Medicine, $\sigma$ 276, 303.

Strauss, J. (1968). Tris (hydroxymethyl) amino-methane (THAM): 응 a pediatric evaluation. Pediatrics, 41, 667.

Swanson, A. G. (1960). Potential harmful effects of treating of pulmonary encephalopathy with a carbon dioxide buffering $N$ agent. American fournal of the Medical Sciences, 240, 433.

Troelstra, J. A., Jonxis, J. H. P., Visser, H. K. A., and van der ${ }^{\text {U }}$ Vlught, J. J. (1964). Metabolism and acid-base regulation in R.D.S.: treatment with THAM. In Nutricia Symposium on $\mathrm{O}$ the Adaptation of the Newborn Infant to Extra-uterine Life, p. 185 . Ed. by J. H. P. Jonxis, H. K. A. Visser, and J. A. Troelstra. Stenfert Kroese, Leyden.

Usher, R. (1963). Reduction of mortality from respiratory distress syndrome of prematurity with early administration of intravenous glucose and sodium bicarbonate. Pediatrics, 32, 966 